\title{
Evidence-based intraoperative microbreak activities for reducing musculoskeletal injuries in the operating room
}

\author{
Krista A. Coleman Wood ${ }^{\mathrm{a}}$, Bethany R. Lowndes ${ }^{\mathrm{b}, \mathrm{c}}$, Ryan J. Buus ${ }^{\mathrm{d}}$ and M. Susan Hallbeck ${ }^{\mathrm{b}, \mathrm{c}, *}$ \\ ${ }^{a}$ Motion Analysis Laboratory, Mayo Clinic, Rochester, MN, USA \\ ${ }^{\mathrm{b}}$ Robert D. and Patricia E. Kern Center for the Science of Health Care Delivery, Mayo Clinic, Rochester, \\ $M N, U S A$ \\ ${ }^{\mathrm{c}}$ Department of Health Sciences Research, Mayo Clinic, Rochester, MN, USA \\ ${ }^{\mathrm{d}}$ Department of Physical Medicine and Rehabilitation, Mayo Clinic, Rochester, MN, USA
}

Received 26 May 2017

Accepted 3 November 2017

\begin{abstract}
.
BACKGROUND: Neuromusculoskeletal pain and fatigue have been self-reported by over 70\% surgeons who perform minimally invasive surgery (MIS). These problems can become impairments impacting surgical performance, patient outcomes, and career longevity. Human factors engineering has identified microbreaks coupled with activities as a viable strategy to counteract known physical, cognitive, and environmental stressors as well as mitigate neuromusculoskeletal (NMS) problems for workers in office and manufacturing domains.

OBJECTIVE: Develop a novel set of intraoperative surgical microbreaks activities tailored for MIS surgeons to mitigate surgery-induced neuromusculoskeletal fatigue and pain.

METHODS: Using NSM problems identified by practitioners and literature, a clinician determined causes and solutions and ranked them based on literature and clinical expertise. Solutions were incorporated into synchronized activities that addressed overarching goals and multiple tissues.

RESULTS: The resulting activities, translating contemporary science in clinical physical medicine and rehabilitation practice and tissue biomechanics, specifically address the overarching goals of: 1) posture correction; 2) normalization of tissue tension and soft tissue mobility/gliding; and 3) relaxation/stress reduction.

CONCLUSION: Surgeons can perform the activities in approximately one minute inside the sterile field. Movements encompassing multiple requirements and engaging multiple body segments are combined to provide an efficient and effective intervention to the target tissues.
\end{abstract}

Keywords: Surgery, neuromusculoskeletal pain, soft tissue mobility, posture correction, ergonomics

\section{Introduction}

Advances in both technology and techniques, particularly in the 1980s and 1990s, coupled with demand by the public, due to patient benefits [1] such as reduced infection rates and shorter recovery times,

*Address for correspondence: Susan Hallbeck, Mayo Clinic, 200 First St. NW, Rochester, MN 55905, USA. Tel.: +1 507284 0450; E-mail: Hallbeck.susan@mayo.edu. have resulted in increased use of minimally invasive surgery (MIS) instead of open procedures. Unfortunately, the health benefits enjoyed by the patients do not universally extend to the surgeons performing the MIS procedures. Reports of surgeons experiencing discomfort and injury began to appear in the early 1990s [1-3]. This trend is expected to continue as techniques such as laparoendoscopic single site surgery (LESS) [4] and natural orifice translumenal 
endoscopic surgery (NOTES) [5] are further developed and widely implemented.

Surveys of MIS surgeons across a multitude of surgical disciplines have reported musculoskeletal pain and fatigue [6-13]. The severity of problems reported by MIS surgeons varies, with most surgeons reporting neuromusculoskeletal symptoms during the MIS procedures [8] and others identifying symptoms that persist beyond the operative time $[6,14]$ and extend beyond the work day [12]. Neuromusculoskeletal fatigue, impairment, and injuries have been shown to adversely affect MIS performance, patient safety, and surgeon career longevity [15-20]. The impact of suboptimal health on the ability of surgeons to perform quality MIS procedures is a major concern in hospitals worldwide [9, 21-23], prompting calls by medical practitioners and human factors engineers to request modification of the "hostile" and "dangerous" environment encountered by MIS surgeons [9, 10, 24, 25].

Environmental factors contributing to neuromusculoskeletal problems have been identified in MIS operating rooms [3, 26-28]. Increased complexity and longer duration procedures were noted to have a deleterious effect on the health of surgeons performing MIS [9, 29]. More awkward postures have been identified in all upper extremity joints during MIS procedures when compared with similar open incision procedures $[3,4,30]$. Studies have identified that relatively unchanging static postures are assumed by MIS practitioners throughout their surgical procedures [28, 29]. These have not been addressed by redesign of the operating room (OR) and some cannot be designed out due to patient factors; thus, surgeons continue to perform surgeries in sub-optimal working conditions over extended durations. Strong evidence presented in ergonomics literature suggests a causal relationship between musculoskeletal disorders and awkward and/or sustained postures, especially those with force [31-33].

Anatomic regions often identified as problematic by MIS practitioners are the back, neck and hands $[9,12,34,35]$ with shoulder problems occasionally cited in similar numbers $[14,36]$. Tissues identified by MIS surgeons as the source of discomfort include muscles, tendons, ligaments, and nerves; all of which have been associated with suboptimal musculoskeletal mechanics in the operating room (OR) [34]. Common to all these regions and recognized as contributing to pain and dysfunction is the vast network of richly innervated connective tissues (fascia) surrounding and supporting all neuromusculoskeletal tissues [37, 38]. When functioning optimally, elements within the extracellular matrix (ECM) of fascia allow muscles, tendons, nerves, and elements of the vascular system to slide and glide on one another and also provide nutrition, protection, and cellular communication [39]. Poorly functioning fascia creates a sensation of "stiffness" [40] and discomfort [38], which can be ameliorated by offloading tissue in tension and reinstating normal tissue mobility (i.e. sliding and gliding).

Successful interventions to protect MIS practitioners from discomfort and injury must target the neuromusculoskeletal tissues compromised by the sustained and awkward positions. A potential solution adapted from office [41, 42] and industry [43] ergonomics is the use of periodic work breaks suggested by Engelmann (2011) [44] and Dorion and Darveau (2013) [45]. We recently completed a study on the feasibility of incorporating simple callisthenic stretching exercises into a one minute microbreak every 20-40 minutes during MIS procedures [46, 47]. While the microbreaks were widely accepted by surgeons and indicated as helpful, the issues that they have recognized as causing pain, dysfunction, and fatigue were not directly addressed. This manuscript describes the evidence-based creation of shorter, more efficient, and targeted microbreak activities targeted at their neuromuskuloskeletal health which could be incorporated into their surgical workflow in the operating room without scrubbing out of the procedure or impacting patient safety.

\section{Methods for novel evidence-based activities}

Using principles of clinical guideline development [48], we analyzed problems identified by MIS practitioners to determine causes and solutions and proposed a set of activities to incorporate into intraoperative microbreaks (see Fig. 1). These activities were derived from contemporary literature in tissue biomechanics and clinical neuromusculoskeletal (NMS) health and integrated with clinical expertise on the need and manor in which to complete the activities. This guideline was a part of an overall effort to apply NSM interventions to reduce work-related pain, injury in illness in surgeons.

A specific problem was identified through surgeonreported symptoms and ergonomic literature. This was described in the introduction. A list of potentially affected tissues (muscles, nerves, joints) that could have caused the problem was generated by a 

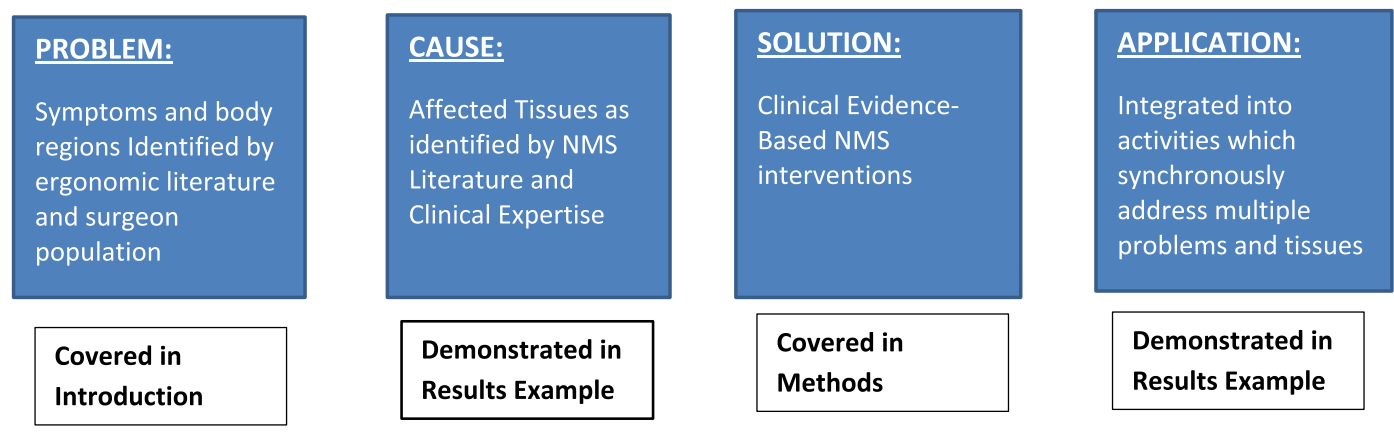

Fig. 1. Process flowchart for development of microbreak activity creating guideline.

physical therapist with NMS health expertise and an ergonomist based on knowledge of the MIS practitioners postures. Tissues potentially affected were ranked in order of those most likely involved according to contemporary medical and MIS ergonomics literature. To resolve the causes of the identified problems, evidence-based clinical interventions were selected to address the needs of the specific tissues and again ranked in order of the number of tissue needs and magnitude of relief each intervention could provide. The interventions were then integrated into activities which addressed multiple problems simultaneously and adhered to the restrictions of the sterile field for MIS practitioners.

The process of creating the guideline for these activities included literature-based work integrated with clinical expertise on the subject and expertise on work-related musculoskeletal risk exposure. The activities proposed represent solutions to address issues identified by MIS providers and meet three overarching goals: 1) posture correction; 2) normalization of tissue tension and soft tissue mobility/gliding; and 3) relaxation/stress reduction. The following paragraphs will describe the process of merging clinical decisions with the supporting literature for the accomplishment of incorporating the three overarching goals into these activities. A summary of the guideline formation for the three overarching is available in Table 1.

\subsection{Posture correction}

Posture correction consists of activities to reposition the head, neck, torso, and extremities. These activities offload tissues and structures which are overloaded in either compression or tension due to positions required by MIS procedures and equipment, thus restoring anatomic loading of the articular surfaces in the spinal column and a balanced posture. Posture correction will benefit tissues which, because of the awkward MIS positioning, are subjected continuous tension loading such as joint capsules and constant muscle contractions [49]. Realignment of posture will also alleviate pressure on those soft tissues which the MIS positions statically hold against a rigid structure, such as nerves or vascular structures compressed over a bone or joint [50-52].

\subsection{Normalization of tissue tension and soft tissue mobility/gliding}

Soft tissue mobility activities prevent stasis in the ECM fluid the preventing increased metabolic waste accumulation [53]. These activities allow soft tissues to undergo a spectrum of tensioning between slack and fully elongated, thus relieving tension and likely decreasing the discomfort from tissues which have been under a static constant tension [51, 54]. Activities are selected and integrated to cross multiple joints and limb segments producing a mild elongating and slackening throughout the entirety of muscle, nerve, vascular and fascial tissues [55]. Joints are gently moved through a mid-range providing lubrication to articular surfaces and relieving joints from the protracted compression loading induced by MIS positioning. Introducing a spectrum of normal tensioning to the soft tissues also helps reestablish normal stretch reflexes [56].

\subsection{Relaxation/stress reduction}

Relaxation is achieved by activities selected to address modulation of muscle sympathetic activity. Movement of the head on the neck and the neck on the thoracic spine are key components in modulating muscle sympathetic activity of both the axial skeleton 
Table 1

Summary of evidence-based solutions for integration in intraoperative microbreak activities

\begin{tabular}{|c|c|c|c|c|c|c|}
\hline \multirow[t]{3}{*}{ Overarching Goal } & \multirow[t]{3}{*}{ Solution } & \multirow[t]{2}{*}{ Reason } & \multirow[t]{3}{*}{ Risk } & \multirow[t]{2}{*}{ Benefits } & \multicolumn{2}{|c|}{ Costs of alternatives } \\
\hline & & & & & Acute & Chronic \\
\hline & & Clinical & & \multicolumn{3}{|l|}{ Literature evidence } \\
\hline Posture correction & $\begin{array}{l}\text { Activities are } \\
\text { needed to } \\
\text { offload tissues } \\
\text { and structures } \\
\text { that are } \\
\text { overloaded. }\end{array}$ & $\begin{array}{l}\text { Necessary to } \\
\text { reposition the head, } \\
\text { neck, torso, and } \\
\text { extremities and } \\
\text { improve tissue } \\
\text { health. }\end{array}$ & $\begin{array}{l}\text { Localized and } \\
\text { acute } \\
\text { discomfort or } \\
\text { tightness. }\end{array}$ & $\begin{array}{l}\text { Decrease muscle } \\
\text { fatigue and } \\
\text { vascular occlusion } \\
\text { secondary to } \\
\text { muscle } \\
\text { contractions [49]. }\end{array}$ & $\begin{array}{l}\text { Increased muscle } \\
\text { fatigue, vascular } \\
\text { occlusion and } \\
\text { diminished } \\
\text { interstitial fluid } \\
\text { load support in } \\
\text { articular } \\
\text { surfaces [63]. }\end{array}$ & $\begin{array}{l}\text { *Work Absence } \\
{[64,65]} \\
{ }^{*} \text { Decreased } \\
\text { Physical and } \\
\text { Mental Health } \\
{[36,66,67]} \\
{ }^{*} \text { Decreased Job } \\
\text { Performance } \\
\text { [68] }\end{array}$ \\
\hline $\begin{array}{l}\text { Normalization of } \\
\text { tissue tension } \\
\text { and soft tissue } \\
\text { mobility/gliding }\end{array}$ & $\begin{array}{l}\text { Joints should be } \\
\text { gently moved } \\
\text { through a } \\
\text { midrange } \\
\text { providing } \\
\text { lubrication to } \\
\text { articular } \\
\text { surfaces. }\end{array}$ & $\begin{array}{l}\text { Must be incorporated } \\
\text { to prevent stasis in } \\
\text { the ECM. }\end{array}$ & & $\begin{array}{l}\text { Removal of } \\
\text { metabolic waste } \\
\text { from local ECM } \\
\text { and restoration of } \\
\text { mobility of soft } \\
\text { tissue structures } \\
\text { [53]. }\end{array}$ & $\begin{array}{l}\text { Increased } \\
\text { metabolic waste } \\
\text { build up leading } \\
\text { to fatigue, } \\
\text { myalgia and } \\
\text { weakness [53]. } \\
\text { Vascular } \\
\text { occlusion [51]. }\end{array}$ & \\
\hline $\begin{array}{l}\text { Relaxation/stress } \\
\text { reduction }\end{array}$ & $\begin{array}{l}\text { Activities should } \\
\text { be included to } \\
\text { address } \\
\text { modulation of } \\
\text { muscle } \\
\text { sympathetic } \\
\text { activity. }\end{array}$ & $\begin{array}{l}\text { This will enhance the } \\
\text { posture correction } \\
\text { and soft tissue } \\
\text { mobility activities. }\end{array}$ & & $\begin{array}{l}\text { Decreased muscle } \\
\text { sympathetic nerve } \\
\text { activity. Potential } \\
\text { increased muscle } \\
\text { efficiency. } \\
\text { Potential } \\
\text { decreased pain } \\
\text { sensitivity [53]. }\end{array}$ & $\begin{array}{l}\text { Increased muscle } \\
\text { tension and } \\
\text { fatigue [49]. }\end{array}$ & \\
\hline
\end{tabular}

as well as upper and lower extremities [57]. Activities which down-regulate muscle sympathetic activity are performed early in the series accompanied by deep breathing to provide a foundation of relaxation and stress reduction which further enhance the posture correction and soft tissue mobility activities.

The activities are integrated into a flowing series of movements similar to "Tai Chi", providing seamless and efficient attention to multiple anatomic areas and tissues simultaneously. All proposed activities were designed or adapted to meet OR sterile field and hand placement constraints and are compatible with movement within the confined OR environment. The sterile field within the OR is the sterile environment around the patient. If the surgeon remains in the sterile field with his/her hands in front of the body and above the waist, the microbreak activities can take place without the interruption of the surgeon to "scrub out". Thus, s/he can leave on the current gloves, gown, etc. preventing the need to resanitize their hands/arms and doff and re-don new gloves and gown which can take precious surgical time. In addition, the total duration of the activities needs to be minimized for patient safety and financial constraints.

\section{Results}

This section demonstrates the results from addressing neuromusculoskeletal complaints in the MIS surgical workforce and determining an implementable solution. It contains an example of the process of applying the created guidelines to implement targeted activities for one problem (neck pain) with an in-depth description of a subset of four integrated activities, selected to mitigate common problems identified by MIS surgeons. There will be an italicized instruction and an explanation following each instruction segment.

\subsection{Neck example}

An example demonstrating the use of the guideline is shown in Table 2. Beginning with the two most common problems specified by MIS practitioners, neck pain and the feeling of tension, the analysis begins with identification of potential causes for each problem. The list of tissues potentially involved in causing the problem are then ranked, with those most likely causing the problem higher on the list, based on a combination of ergonomic literature and expertise 
Table 2

Example of guideline application for neck pain and feeling of tension

\begin{tabular}{|c|c|c|c|}
\hline Problem & Causes & Solutions & Application \\
\hline $\begin{array}{l}\text { Problem identified by } \\
\text { MIS practitioner } \\
\text { and ergonomic } \\
\text { Literature }\end{array}$ & $\begin{array}{l}\text { NMS and ergonomic literature } \\
\text { and physical therapist expertise }\end{array}$ & $\begin{array}{l}\text { NMS evidence literature on } \\
\text { interventions }\end{array}$ & $\begin{array}{l}\text { Integration of solutions } \\
\text { (overarching goals) to address } \\
\text { multiple problems based on } \\
\text { clinical and ergonomics } \\
\text { expertise } \\
\end{array}$ \\
\hline \multirow{4}{*}{ Neck pain } & $\begin{array}{l}\text { Tissues involved based on } \\
\text { NMS/Ergo Expertise } \\
\text { - Facet impingement/decreased } \\
\text { joint mobility and nutrition to } \\
\text { the articular surfaces } \\
\text { - Nerve compression } \\
\text { - Muscle overuse } \\
\text { - Decreased upper extremity } \\
\text { circulation } \\
\end{array}$ & $\begin{array}{l}\text { Evidence based clinical } \\
\quad \text { intervention identified } \\
\text { - Slow mobilization of cervical } \\
\text { facet joints } \\
\text { - Decompression of facet joints } \\
\text { - Decrease muscle contraction } \\
\text { - Neural mobilization } \\
\text { - Down regulation of muscle } \\
\text { sympathetic activity } \\
\end{array}$ & \multirow{2}{*}{$\begin{array}{l}\text { 1) Base position: } \\
\text { a. Beginning the process } \\
\text { of posture correction } \\
\text { (PC, NT, SR) } \\
\text { b. Modulation of muscle } \\
\text { sympathetic activity } \\
\text { (NT, SR) } \\
\text { c. Normalization of tissue } \\
\text { tension and relaxation } \\
\text { (PC, NT, SR) } \\
\text { d. Decompression of facet } \\
\text { joints (PC, NT, SR) }\end{array}$} \\
\hline & $\begin{array}{l}\text { Tissues ranked by most likely } \\
\text { affected based on NMS/Ergo } \\
\text { literature }\end{array}$ & $\begin{array}{l}\text { Intervention ranked by number } \\
\text { of needs and magnitude } \\
\text { provided }\end{array}$ & \\
\hline & $\begin{array}{l}\text { 1) Muscle overuse } \\
\text { 2) Facet impingement/ } \\
\text { decreased joint mobility and } \\
\text { nutrition to the articular } \\
\text { surfaces } \\
\text { 3) Nerve compression }\end{array}$ & $\begin{array}{l}\text { 1) Down regulation of muscle } \\
\text { sympathetic activity } \\
\text { 2) Slow mobilization of cervical } \\
\text { facet joints } \\
\text { 3) Decompression of facet joints } \\
\text { 4) Decrease muscle contraction } \\
\text { 5) Neural mobilization }\end{array}$ & $\begin{aligned} \text { 2) Deep breathing: } \\
\text { a. Down regulation of muscle } \\
\text { sympathetic activity } \\
\text { (NT, SR) } \\
\text { b. } \begin{array}{l}\text { Slow mobilization } \\
\text { of thoracic and costal joints } \\
\text { (PC, NT, SR) }\end{array}\end{aligned}$ \\
\hline & $\begin{array}{l}\text { Tissues involved based on } \\
\text { NMS/Ergo Expertise } \\
\text { - Muscle overuse due to } \\
\text { increased muscle contraction } \\
\text { demanded for: } \\
\text { • head stabilization } \\
\text { - neck stabilization } \\
\text { - scapular stabilization } \\
\text { - glenohumeral joint } \\
\text { stabilization } \\
\text { - wrist extensor and long } \\
\text { finger flexor } \\
\text { - Decreased upper extremity } \\
\text { circulation } \\
\text { • Decreased respiratory rate } \\
\text { - Postural stasis } \\
\end{array}$ & $\begin{array}{l}\text { Evidence based clinical } \\
\text { intervention identified } \\
\text { - Neural mobilization } \\
\text { - Slow mobilization of upper } \\
\text { extremity muscles } \\
\text { - Down regulation of muscle } \\
\text { sympathetic activity } \\
\text { - Vascular decompression } \\
\text { - Slow mobilization of thoracic } \\
\text { and costal joints } \\
\text { - Slow mobilization of upper } \\
\text { extremity joints }\end{array}$ & $\begin{array}{l}\text { 3) Turn Head: } \\
\text { a. Down regulation of muscle } \\
\text { sympathetic activity } \\
\text { (NT, SR) } \\
\text { b. Normalization of tissue } \\
\text { tension and relaxation } \\
\text { (PC, NT, SR) } \\
\text { c. Slow mobilization of facet } \\
\text { joints (PC, NT, SR) } \\
\text { d. Anterior neck muscle } \\
\text { relaxation (NT) } \\
\text { e. Normalization of nerve } \\
\text { tissue tension (NT) }\end{array}$ \\
\hline \multirow[t]{3}{*}{ Feeling of tension } & $\begin{array}{l}\text { Tissues ranked by most likely } \\
\text { affected based on NMS/Ergo } \\
\text { literature }\end{array}$ & $\begin{array}{l}\text { Intervention ranked by number } \\
\text { of needs and magnitude } \\
\text { provided }\end{array}$ & \multirow{3}{*}{$\begin{array}{l}\text { Where: } \\
\text { PC }=\text { Posture Correction } \\
\text { NT }=\text { Normalization of Tissue } \\
\text { tension and soft tissue } \\
\text { mobility/gliding } \\
\text { SR }=\text { Relaxation/Stress Reduction }\end{array}$} \\
\hline & $\begin{array}{l}\text { 1) Decreased respiratory } \\
\text { inspiration mobility } \\
\text { 2) Postural stasis } \\
\text { 3) Muscle overuse }\end{array}$ & $\begin{array}{l}\text { 1) Down regulation of muscle } \\
\text { sympathetic activity } \\
\text { 2) Slow mobilization of thoracic } \\
\text { and costal joints }\end{array}$ & \\
\hline & $\begin{array}{l}\text { 4) Decreased upper extremity } \\
\text { circulation } \\
\text { 5) Decreased respiratory rate }\end{array}$ & $\begin{array}{l}\text { 3) Slow mobilization of upper } \\
\text { extremity muscles } \\
\text { 4) Slow mobilization of upper } \\
\text { extremity joints } \\
\text { 5) Neural mobilization } \\
\text { 6) Vascular decompression }\end{array}$ & \\
\hline
\end{tabular}




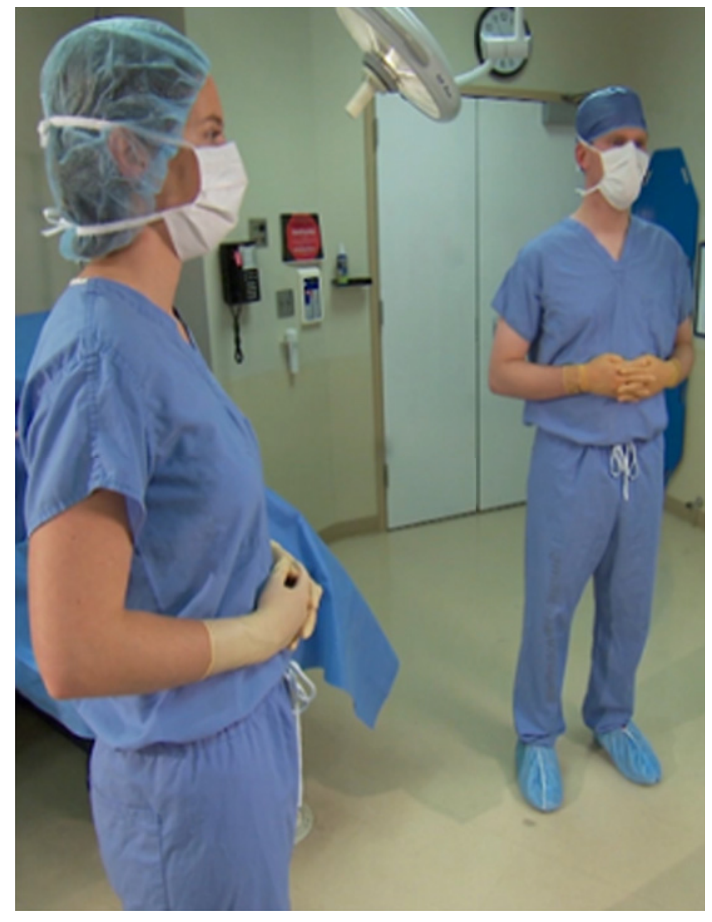

Fig. 2. Activity 1 Stand tall (base position for microbreak activities).

of a NMS trained physical therapist. Solutions were identified using clinical interventions which address specific tissue needs and mitigate their causing the problem. These were identified based on evidence from contemporary clinical literature. The physical therapist then integrated multiple interventions into activities which combined the solutions in a sequence that can build on the benefits of the prior intervention. The leveraging of the benefits from one solution to enhance a subsequent intervention makes the sequence of the activities critical in order to optimize benefits while minimizing the time required for the activities. The integrated activities achieve the overarching goals of: 1) posture correction (PC); 2) normalization of tissue tension and soft tissue mobility/gliding (NT); and 3) relaxation/stress reduction (SR), as indicated in Table 2.

\subsection{Sample activities}

Performing the first two activities (Figs. 2 and 3) establishes a foundation of posture correction and decreased muscle sympathetic activity, thus initiating relaxation and establishing a relaxed stance from which to move into other activities which focus more narrowly on the greatest areas of concern as defined

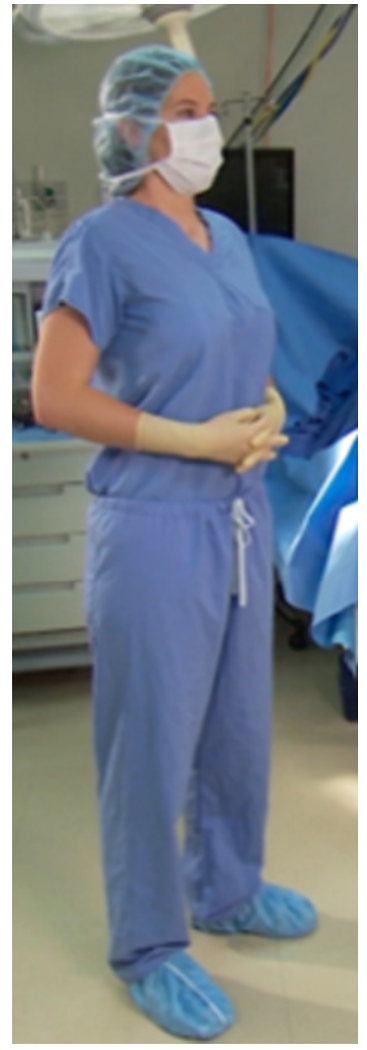

Fig. 3. Deep Breath (Take a deep breath in, filling out your ribs. Keep your chest high as you breathe out).

by the MIS surgeons. The next activities address the most frequently reported areas of concern for fatigue, pain and dysfunction, specifically the neck, shoulder and spine (upper and lower back) [46]. For subsequent activities, care was taken to isolate specific tissues addressing areas of concern and to create a sequence, building upon the neuromusculoskeletal relief afforded by the previous activities. The third activity is an example of activities selected to address a tissue-specific area of concern, the neck (Fig. 4). These activities will be piloted in a web-app with a reminder poster which can be placed in the OR.

\subsubsection{The base position for these activities is standing tall with your feet approximately shoulder width apart. Your fingers are interlaced and held at the level of your belly button}

A "base" position is identified as a balanced standing posture (Fig. 2). Stability is achieved for surgeons by standing tall with their feet approximately shoulder width apart. Surgeons are instructed to interlace their fingers and hold them in front of 
their torso at a level which preserves the sterile field as they progress through the activities. Standing tall in a stable, balanced position begins the process of posture correction, tissue tension normalization and stress reduction. This position decreases demand on the posterior neck, back, and scapular stabilizing muscles, all of which have been subjected to prolonged contractions in either elongated or shortened positions as they function to optimize the head and upper extremity postures needed by the MIS surgeon. Offloading the posterior muscles by standing upright triggers a down regulation of muscle sympathetic activity which allows the muscles to relax thereby promoting more optimal vascular and ECM fluid flow. Standing upright also gently elongates the muscles and structures on the anterior aspect of the neck and torso which is especially important in gently lifting and separating the ribs to allow for enhanced inspiration.

\subsubsection{Take a deep breath in, filling out your ribs. Keep your chest high as you breathe out}

Deep breathing from the base position further enhances the posture correction, tissue mobility, muscle relaxation and stress reduction. Deep inspiration gently mobilizes the ribs by lifting and separating them and contributes to further sympathetic down regulation of muscle activity enhancing tissue tension optimization and stress reduction. Keeping the chest "high" during exhalation continues the separation of the ribs providing optimal space for subsequent respirations. This is demonstrated in Fig. 3.

\subsubsection{Turn your head toward the right looking over your shoulder, feeling the lengthening in the back of your neck}

This activity engages spinal rotation beginning at $\mathrm{C} 1$ and progressing inferiorly to approximately $\mathrm{T} 2$. During this top-down activity, down modulation of muscle sympathetic activity occurs at each vertebral segment as muscles are gently lengthened. The lengthening of the neck muscles provides relief from the prolonged static contractions required to sustain an optimal head position for the surgical tasks. The rotation causes muscle relaxation on one side of the neck providing relief of facet joint compression. The gentle rotation by turning the head from side to side promotes normal sliding and gliding of the facet joints for articular surface nutrition and provides refreshing of the ECM fluids. Muscle relaxation reduces compression loads on the discs. The rotation

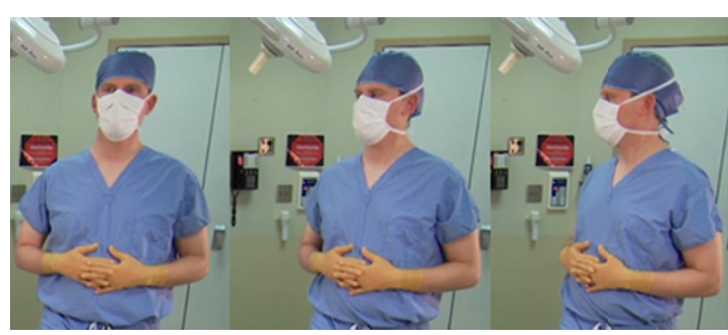

Fig. 4. Turn your head toward the right looking over your shoulder, feeling the lengthening in the back of your neck.

of the head and neck also elongates one side of the anterior neck muscles and relaxes the other side. As the end of the anterior neck muscle elongation approaches, the clavicle is gently lifted providing elongation of sub-clavicular tissues and providing increased freedom for rib movement during inspiration. The increased relaxation in the sub-clavicular region combined with relaxation of anterior neck muscles releases compression on cervical and brachial plexus nerves. Once the plexus compression is relieved, activities promoting neural gliding can be introduced allowing nerves to slide and glide normally thus providing lubrication and nourishment in their ECM. This activity is partially shown in Fig. 4.

\subsubsection{Summary of activities}

These microbreak activities and explanations demonstrate how multiple joints and soft tissues are impacted throughout the activities during the short surgical break. Each subsequent activity builds upon prior activities to enhance relaxation of muscles, provide decompression of joints and soft tissues, and allow for neural gliding and mobility. Through the combination of clinical expertise and supporting literature, these activities have been selected and organized to optimize the restricted time and space allowed in the surgical environment to enhance the 1) posture correction; 2) normalization of tissue tension and soft tissue mobility/gliding; and 3) relaxation/stress reduction, leading to improved neuromusculoskeletal health and reduced fatigue, pain, and dysfunction for MIS surgeons.

\section{Discussion}

Taking breaks is widely practiced across many workplaces, particularly during prolonged activities and has been advocated as a technique to sustain employee productivity [58]. Office workers 
experience decreased levels of discomfort when they take short breaks to change their posture [12]. Participating in five-minute breaks or "micro-pauses" for each hour of a prolonged session is recommended by OSHA as a method to provide time for muscles and tendons to recover [58]. For MIS providers during surgical procedures, neither the length of time a procedure can be interrupted while still maintaining the positive patient outcomes, nor the length of a "microbreak" sufficient to avoid provider discomfort has been defined. A simple break from surgery without the activities might not counteract the awkward postures assumed during MIS, therefore, these activities were developed for use during a micro break for improved outcomes. Self-reported feedback from MIS providers participating in prior studies at our institution have indicated a preference that microbreaks from the surgical procedure be approximately one minute in length and able to be performed in the sterile field. This reduces the length of the interruption by allowing the surgical team to remain at the operating table. Our previous work indicated that a one-minute microbreak every 20-40 minutes was feasible during MIS procedures [46, 47]. Therefore, the efficiency of these activities assists with optimizing the restricted time and space allowed in the surgical environment to increase neuromuscular health.

The majority of programs promoted for use in office, industrial, or athletic settings [59] identify a stretching activity consisting of a 10 to 30 second hold time with 3-5 repetitions. Many of these for the upper extremities are described and demonstrated as moving joints and soft tissues past the end of available volitional movement with over-pressure provided by the contralateral limb [60]. There are several problems with this approach. First, performing stretches in this manner requires a more prolonged break than can be accommodated during surgical procedures to address all problematic areas previously identified by MIS providers. Second, if the goal is to provide relief to tissues which have been under prolonged tension or compression, passively moving a joint and adding additional pressure will actually increase tension in any tissue which crosses the obtuse joint angle and increase compression in tissues on the acute joint angle side. Placing joints at the end of available movement generally causes increased forces in joint ligaments and compression of the articular surfaces risking overuse injury to those tissues. Passively holding a joint at the end of motion creates synovial fluid stasis, thus decreasing joint nutrition.
Performing static stretching also reduces fluid and nutrient flow in the soft tissue ECM which is not beneficial to tissues which have been compromised by postures/positions of surgical personnel. Finally, evidence is growing that active stretch achieved via volitional movement is more effective than passive stretch $[61,62]$. The dynamic nature of the intraoperative microbreak activities we have proposed for MIS surgeons place no additional stress on joints and rely on volitional movement to reduce tension and compression of tissues across multiple joints simultaneously allowing restoration of the ECM homeostasis and promoting normal sliding and gliding between tissues.

This work represents evidence-based solutions and applications to address the neuromuskuloskeletal concerns in the operating room, however, it is not a complete systematic review of the problems, causes, solutions or applications. While these exercises do focus on three key areas of improvement for the MIS surgeons, the exercises do not include strengthening. Strength cannot be addressed in this short of a time period and should be addressed on an individual basis. Activities focusing on the legs could not be addressed due to the constraints of the OR environment. Additionally, overhead activities would be ideal for addressing NMS concerns with shoulders and the neck. Since this motion required movement outside of the sterile zone (over the head), they were not incorporated into the activities. These microbreak activities will be implemented through pilot studies within a web-app. Future work will include activities that can be incorporated between procedures to address the legs and overhead movement. Strength should be addressed on an individual basis outside of the OR as should be other pre-existing NMS injuries. Subsequent studies will aim to compare microbreaks with and without activities to measure effectiveness of the activities.

\section{Conclusions}

A novel set of activities designed to be performed by MIS surgeons during intraoperative microbreaks has been described. Rationale for the activities has been drawn from contemporary neuromusculoskeletal and human factors engineering literature. Based on a multi-center trial [46], MIS practitioners participating in the novel microbreak activities we describe experience significantly less discomfort and fatigue, with increased subjective ratings of physical 
performance, mental focus and without increasing their surgical duration times. Thus, evidence-based activities addressing specific musculoskeletal challenges posed by the operating room onto the surgeon can be created to restore posture, restore soft tissue mobility and reduce stress with minimal impact to the surgical workflow. This work resulted in an integrated intervention for addressing multiple areas of pain and multiple tissues through targeted and synchronized activities.

\section{Conflict of interest}

None to report.

\section{References}

[1] Kano N, Yamakawa T, Kasugai H. Laparoscopic surgeon's thumb. Archives of Surgery. 1993;128(10):1172.

[2] McCrory B, LaGrange CA, Hallbeck M. Quality and safety of minimally invasive surgery: Past, present, and future. Biomedical Engineering and Computational Biology. 2014;6:1

[3] Matern U. Ergonomic deficiencies in the operating room: Examples from minimally invasive surgery. Work. 2009;33(2):165-8.

[4] McCrory B, Lowndes BR, Wirth LM, De Laveaga AE, Lagrange CA, Hallbeck MS. Ergonomic evaluation of laparoendoscopic single-site surgery ports in a validated laparoscopic training model. Work. 2012;41(Supplement 1):1884-90.

[5] Tessier C, Zhang L, Cao CG. Ergonomic considerations in natural orifice translumenal endoscopic surgery (NOTES): A case study. Work. 2012;41(Supplement 1): 4683-8.

[6] Esposito C, Najmaldin A, Schier F, Yamataka A, Ferro M, Riccipetitoni G, et al. Work-related upper limb musculoskeletal disorders in pediatric minimally invasive surgery: A multicentric survey comparing laparoscopic and sils ergonomy. Pediatric Surgery International. 2014;30(4): 395-9.

[7] Kim-Fine S, Woolley SM, Weaver AL, Killian JM, Gebhart JB. Work-related musculoskeletal disorders among vaginal surgeons. International Urogynecology Journal and Pelvic Floor Dysfunction. 2013;24(7):1191-200.

[8] Miller K, Benden M, Pickens A, Shipp E, Zheng Q. Ergonomics principles associated with laparoscopic surgeon injury/illness. Human Factors: The Journal of the Human Factors and Ergonomics Society. 2012;54:1087-92.

[9] Park A, Lee G, Seagull FJ, Meenaghan N, Dexter D. Patients benefit while surgeons suffer: An impending epidemic. Journal of the American College of Surgeons. 2010;210(3):306-13.

[10] Sari V, Nieboer TE, Vierhout ME, Stegeman DF, Kluivers $\mathrm{KB}$. The operation room as a hostile environment for surgeons: Physical complaints during and after laparoscopy. Minimally Invasive Therapy and Allied Technologies. 2010;19(2):105-9.
[11] Stomberg MW, Tronstad S-E, Hedberg K, Bengtsson J, Jonsson P, Johansen L, et al. Work-related musculoskeletal disorders when performing laparoscopic surgery. Surgical Laparoscopy Endoscopy \& Percutaneous Techniques. 2010;20:49-53.

[12] Davis WT, Fletcher SA, Guillamondegui OD. Musculoskeletal occupational injury among surgeons: Effects for patients, providers, and institutions. Journal of Surgical Research. 2014;189(2):207-12.

[13] Dalager T, Søgaard K, Bech KT, Mogensen O, Jensen PT. Musculoskeletal pain among surgeons performing minimally invasive surgery: A systematic review. Surgical Endoscopy. 2016:1-11.

[14] Franasiak J, Ko EM, Kidd J, Secord AA, Bell M, Boggess JF, et al. Physical strain and urgent need for ergonomic training among gynecologic oncologists who perform minimally invasive surgery. Gynecologic Oncology. 2012;126(3):43742.

[15] Elhage O, Challacombe B, Shortland A, Dasgupta P. An assessment of the physical impact of complex surgical tasks on surgeon errors and discomfort: A comparison between robotic-assisted, laparoscopic and open approaches. BJU International. 2014:n/a-n/a.

[16] Galleano R, Carter F, Brown S, Frank T, Cuschieri A. Can armrests improve comfort and task performance in laparoscopic surgery? Annals of surgery. Comparative Study. 2006;243(3):329-33.

[17] Giberti C, Gallo F, Francini L, Signori A, Testa M. Musculoskeletal disorders among robotic surgeons: A questionnaire analysis. Archivio italiano di urologia, andrologia: Organo ufficiale [di] Societa italiana di ecografia urologica e nefrologica/Associazione ricerche in Urologia. 2014;86(2):95-8.

[18] Montero PN, Acker CE, Heniford BT, Stefanidis D. Single incision laparoscopic surgery (SILS) is associated with poorer performance and increased surgeon workload compared with standard laparoscopy. The American Surgeon. 2011;77(1):73-7.

[19] Vijendren A, Yung M, Sanchez J. The ill surgeon: A review of common work-related health problems amongst UK surgeons. Langenbeck's archives of surgery/Deutsche Gesellschaft fur Chirurgie. 2014;399(8):967-79.

[20] Yurko YY, Scerbo MW, Prabhu AS, Acker CE, Stefanidis D. Higher mental workload is associated with poorer laparoscopic performance as measured by the NASA-TLX tool. Simulation in Healthcare: Journal of the Society for Simulation in Healthcare. 2010;5(5):267-71.

[21] Gridley CM, Nguyen HT. Ergonomics of laparoscopy. Pediatrics Enduorology Techniques: Springer, 2014. pp. 13-22.

[22] Szeto GP, Ho P, Ting AC, Poon JT, Cheng SW, Tsang RC. Work-related musculoskeletal symptoms in surgeons. Journal of occupational rehabilitation. Research Support, Non-U.S. Gov't. 2009;19(2):175-84.

[23] Janki S, Mulder EE, IJzermans JN, Tran TK. Ergonomics in the operating room. Surgical Endoscopy. 2016:1-10.

[24] Craven R, Franasiak J, Mosaly P, Gehrig PA. Ergonomic deficits in robotic gynecologic oncology surgery: A need for intervention. Journal of Minimally Invasive Gynecology. 2013;20(5):648-55.

[25] Vereczkei A, Feussner H, Negele T, Fritzsche F, Seitz T, $\mathrm{Bubb} \mathrm{H}$, et al. Ergonomic assessment of the static stress confronted by surgeons during laparoscopic cholecystectomy. Surgical Endoscopy. 2004;18(7):1118-22. 
[26] Choi SD. A review of the ergonomic issues in the laparoscopic operating room. Journal of Healthcare Engineering. 2012;3(4):587-603.

[27] Lowndes BR, Hallbeck MS. Overview of human factors and ergonomics in the OR, with an emphasis on minimally invasive surgeries. Human Factors and Ergonomics In Manufacturing. 2014;24(3):308-17.

[28] Sutton EH, Park A. 4. Ergonomics in Operating Room Design. In: Soper NJ, Scott-Conner CEH, editors. The SAGES Manual: Springer New York, 2012, pp. 45-59.

[29] Supe A, Kulkarni G, Supe P. Ergonomics in laparoscopic surgery. Journal of Minimal Access Surgery. 2010;6:31().

[30] Nguyen NT, Ho HS, Smith WD, Philipps C, Lewis C, De Vera RM, et al. An ergonomic evaluation of surgeons' axial skeletal and upper extremity movements during laparoscopic and open surgery. The American Journal of Surgery. 2001;182:720-4.

[31] Bernard BP, Putz-Anderson V. Musculoskeletal disorders and workplace factors: A critical review of epidemiologic evidence for work-related musculoskeletal disorders of the neck, upper extremity, and low back. In: (DHHS) USDoHaHS, editor. Cincinnati: National Institute for Occupational Safety and Health, 1997.

[32] Ratzon NZ, Yaros T, Mizlik A, Kanner T. Musculoskeletal symptoms among dentists in relation to work posture. Work. 2000;15(3):153-8.

[33] Alnaser MZ. Occupational musculoskeletal injuries in the health care environment and its impact on occupational therapy practitioners: A systematic review. Work. 2007;29(2):89-100.

[34] Gofrit ON, Mikahail AA, Zorn KC, Zagaja GP, Steinberg GD, Shalhav AL. Surgeons' perceptions and injuries during and after urologic laparoscopic surgery. Urology. 2008;71(3):404-7.

[35] Soueid A, Oudit D, Thiagarajah S, Laitung G. The pain of surgery: Pain experienced by surgeons while operating. International Journal of Surgery. 2010;8(2):118-20.

[36] Ruitenburg MM, Frings-Dresen MH, Sluiter JK. Physical job demands and related health complaints among surgeons. International Archives of Occupational and Environmental Health. 2013;86(3):271-9.

[37] Schleip R, Jäger H, Klingler W. What is 'fascia'? A review of different nomenclatures. Journal of Bodywork and Movement Therapies. Review. 2012;16(4):496-502.

[38] Schilder A, Hoheisel U, Magerl W, Benrath J, Klein $\mathrm{T}$, Treede RD. Sensory findings after stimulation of the thoracolumbar fascia with hypertonic saline suggest its contribution to low back pain. Pain. Research Support, NonU.S. Gov't. 2014;155(2):222-31.

[39] Klingler W, Velders M, Hoppe K, Pedro M, Schleip R. Clinical relevance of fascial tissue and dysfunctions. Current Pain and Headache Reports. 2014;18(8):439.

[40] Stecco C, Pavan P, Pachera P, De Caro R, Natali A. Investigation of the mechanical properties of the human crural fascia and their possible clinical implications. Surgical and radiologic anatomy: SRA. Research Support, Non-U.S. Gov't. 2014;36(1):25-32.

[41] Frank HA, Jacobs K, McLoone H. The effect of a wearable device prompting high school students aged 17-18 years to break up periods of prolonged sitting in class. Work. 2017;56(3):475-82.

[42] Taylor WC, Shegog R, Chen V, Rempel DM, Baun MP, Bush CL, et al. The Booster Break program: Description and feasibility test of a worksite physical activity daily practice. Work. 2010;37(4):433-43.
[43] Trujillo L, Zeng X. Data entry workers perceptions and satisfaction response to the" stop and stretch" software program. Work. 2006;27(2):111-21.

[44] Engelmann C, Schneider M, Kirschbaum C, Grote G, Dingemann J, Schoof S, et al. Effects of intraoperative breaks on mental and somatic operator fatigue: A randomized clinical trial. Surgical endoscopy. Randomized Controlled Trial Research Support, Non-U.S. Gov't. 2011;25(4):1245-50.

[45] Dorion D, Darveau S. Do micropauses prevent surgeon's fatigue and loss of accuracy associated with prolonged surgery? An experimental prospective study. Annals of Surgery. 2013;257(2):256-9.

[46] Park AE, Zahiri HR, Hallbeck MS, Augenstein V, Sutton E, Yu D, et al. Intraoperative "micro breaks" with targeted stretching enhance surgeon physical function and mental focus: A multicenter cohort study. Annals of Surgery. 2016.

[47] Hallbeck M, Lowndes B, Bingener J, Abdelrahman A, Yu D, Bartley A, et al. The impact of intraoperative microbreaks with exercises on surgeons: A multi-center cohort study. Applied Ergonomics. 2017;60:334-41.

[48] Jackson R, Feder G. Guidelines for clinical guidelines: A simple, pragmatic strategy for guideline development. BMJ: British Medical Journal. 1998;317(7156):427.

[49] Kang JH, Jeong BH, Jang JH. Analysis of muscle fatigue of erect spinae caused by treatment table height in ultrasound therapy. Journal of Physical Therapy Science. 2013;25(7):881-3.

[50] Schmid AB, Nee RJ, Coppieters MW. Reappraising entrapment neuropathies-Mechanisms, diagnosis and management. Manual Therapy. 2013;18(6):449-57.

[51] Frey Law LA, Avin KG. Endurance time is joint-specific: A modelling and meta-analysis investigation. Ergonomics. 2010;53(1):109-29.

[52] Avin K, Law LF. Endurance time is joint-specific: A modeling and meta-analysis investigation. Power. 2000:2500.

[53] Søgaard K, Sjøgaard G. Physical activity as cause and cure of muscular pain: Evidence of underlying mechanisms. Exercise and Sport Sciences Reviews. 2017;45(3):136.

[54] Villafañe JH, Silva GB, Bishop MD, Fernandez-Carnero J. Radial nerve mobilization decreases pain sensitivity and improves motor performance in patients with thumb carpometacarpal osteoarthritis: A randomized controlled trial. Archives of Physical Medicine and Rehabilitation. 2012;93(3):396-403.

[55] Topp KS, Boyd BS. Peripheral nerve: From the microscopic functional unit of the axon to the biomechanically loaded macroscopic structure. Journal of Hand Therapy. 2012;25(2):142-52.

[56] Shemmell J, Krutky MA, Perreault EJ. Stretch sensitive reflexes as an adaptive mechanism for maintaining limb stability. Clinical Neurophysiology. 2010;121(10): 1680-9.

[57] Bolton PS, Hammam E, Macefield VG. Neck proprioceptors contribute to the modulation of muscle sympathetic nerve activity to the lower limbs of humans. Experimental Brain Research. 2014;232(7):2263-71.

[58] OSHA. Extended unusual work shifts. Available from: https://www.osha.gov/OshDoc/data_Hurricane_Facts/faqlonghours.html

[59] Garber CE, Blissmer B, Deschenes MR, Franklin BA, Lamonte MJ, Lee IM, et al. Quantity and quality of exercise for developing and maintaining cardiorespiratory, musculoskeletal, and neuromotor fitness in apparently healthy 
adults: Guidance for prescribing exercise. Medicine and Science in Sports and Exercise. 2011;43(7):1334-59.

[60] Galinsky T, Swanson N, Sauter S, Dunkin R, Hurrell J, Schleifer L. Supplementary breaks and stretching exercises for data entry operators: A follow-up field study. American journal of industrial medicine. Randomized Controlled Trial. 2007;50(7):519-27.

[61] van Dyke JM, Bain JLW, Riley DA. Preserving sarcomere number after tenotomy requires stretch and contraction. Muscle and Nerve. 2012;45(3):367-75.

[62] Van Dyke JM, Bain JLW, Riley DA. Stretch-activated signaling is modulated by stretch magnitude and contraction. Muscle and Nerve. 2014;49(1):98-107.

[63] Ateshian GA. The role of interstitial fluid pressurization in articular cartilage lubrication. Journal of Biomechanics. 2009;42(9):1163-76.

[64] Lötters F, Meerding W-J, Burdorf A. Reduced productivity after sickness absence due to musculoskeletal disorders and its relation to health outcomes. Scandinavian Journal of Work, Environment \& Health. 2005, 367-74.
[65] Schultz AB, Edington DW. Employee health and presenteeism: A systematic review. Journal of Occupational Rehabilitation. 2007;17(3):547-79.

[66] Devereux J, Vlachonikolis I, Buckle P. Epidemiological study to investigate potential interaction between physical and psychosocial factors at work that may increase the risk of symptoms of musculoskeletal disorder of the neck and upper limb. Occupational and Environmental Medicine. 2002;59(4):269-77.

[67] Bernard BP, Putz-Anderson V. Musculoskeletal disorders and workplace factors: A critical review of epidemiologic evidence for work-related musculoskeletal disorders of the neck, upper extremity, and low back. National Institute for Occupational Safety and Health, 1997.

[68] Tsutsumi A, Nagami M, Yoshikawa T, Kogi K, Kawakami N. Participatory intervention for workplace improvements on mental health and job performance among bluecollar workers: A cluster randomized controlled trial. Journal of Occupational and Environmental Medicine. 2009;51(5):554-63. 